\title{
Kite Pharma
}

National Cancer Institute

\section{Source}

National Cancer Institute. Kite Pharma. NCI Thesaurus. Code C126406.

A clinical-stage biopharmaceutical company eng aged in the development of cancer immunotherapy products with a primary focus on eng ineered autologous T cell therapy designed to restore the immune system's ability to recognize and eliminate tumors. 